\title{
PENGARUH EKSTRAK ETANOL Centella asiatica TERHADAP JUMLAH SEL NEURON DI KORTEKS PREFRONTALIS TIKUS YANG DIBERI PERLAKUAN STRES
}

\author{
Priyantiningrum, A.K., ${ }^{1}$ Kuswati, $^{2}$ Handayani, E.S. ${ }^{2}$ \\ ${ }^{1}$ Mahasiswa Fakultas Kedokteran Universitas Islam Indonesia \\ ${ }^{2}$ Departemen Anatomi Fakultas Kedokteran Universitas Islam Indonesia
}

\begin{abstract}
ABSTRAK
\section{Latar Belakang}

Stres berdampak pada penurunan fungsional tubuh yang dapat menimbulkan suatu penyakit seperti ketidakmampuan kognitif yang serius, diketahui bahwa kemampuan kognitif diatur pada Korteks Prefrontalis di otak. Respon tubuh terhadap stress berupa kemampuan untuk bertahan hidup hingga apoptosis. Centella asiatica merupakan tanaman obat yang memiliki senyawa triterpen sebagai antioksidan yang mampu memproteksi sel untuk dapat terhindar dari apoptosis.
\end{abstract}

\section{Tujuan Penelitian}

Penelitian ini bertujuan untuk mengetahui pengaruh pemberian ekstrak etanol pegagan (Centella asiatica) terhadap jumlah sel neuron di korteks prefrontalis tikus putih (Rattus norvegicus) yang diberi perlakuan stres

\section{Metode Penelitian}

Penelitian ini merupakan penelitian eksperimental dengan menggunakan rancangan post test-with control group. Subyek penelitian ini menggunakan 12 tikus dewasa (Rattus norvegicus) galur Wistar yang memenuhi kriteria inklusi dan eksklusi. Subyek terbagi sama rata menjadi kelompok kontrol dan perlakuan. Kedua kelompok dilakukan stres restrain selama 21 hari. Tiga puluh menit sebelum stress, kelompok kontrol diberikan Pulvis Gum Arabica 3\%. Kelompok perlakuan diberikan ekstrak etanol pegagan 300 $\mathrm{mg} / \mathrm{kgBB} / \mathrm{hari}$. Perbedaan jumlah sel neuron rerata pada seluruh lapang pandang setiap kelompok dianalisis dengan uji $T$-test independent.

\section{Hasil}

Hasil penelitian ini menunjukkan bahwa jumlah sel neuron rerata di Korteks Prefrontalis setelah pemberian ekstrak etanol pegagan (Centella asiatica) lebih banyak dibandingkan kelompok kontrol ( $p$-value 0,004; CI 95\%).

\section{Kesimpulan}

Pemberian ekstrak etanol pegagan (Centella asiatica) signifikan meningkatkan jumlah sel neuron di Korteks Preftontalis tikus (Rattus norvegicus) yang diberi perlakuan stres, dibanding tikus kontrol yang tidak diberikan pegagan

Kata Kunci: Stres Restrain, Centella asiatica, Korteks Prefrontalis, Rattus norvegicus 


\section{ABSTRACT}

\section{Background}

Stress affects functional of the body and causes a serious cognitive incapacity which cognitive sets in prefrontal cortex of the brain. The body's response to stress is ability to survive until apoptosis. Centella asiatica is one of herb because its triterpene compounds that act as antioxidants and can protect the cells to avoid apoptosis.

\section{Objective}

This study was carried out to determine the effect of ethanol extract gotu kola (Centella asiatica) in the number of neurons on the prepfrontal cortex rat (Rattus novergicus)

\section{Methods}

This study was an experimental used post-test with control group design. The subjects were 12 adult rats (Rattus norvegicus) Wistar which fulfilled inclusion and exclusion criteria. Subjects equally divided into control and treatment groups. The control group was induced stress. The treatment group was induced stress and treated ethanol extract of Centella asiatica $300 \mathrm{mg} / \mathrm{kg} /$ day. Restraint stress performed for 21 days. The differences in the mean number of neurons on the entire field of view were analyzed by independent $t$-test.

\section{Results}

The results of this study showed that administration of ethanol extract gotu kola (Centella asiatica) effect on the decrease in number of neurons in the prefrontal cortex (p-value 0.004; CI 95\%).

\section{Conclusion}

Ethanol extract gotu kola (Centella asiatica) increased significantly number of neurons on the Preftontal cortex rat (Rattus norvegicus) group induced of stress.

Keywords: restraint stress, Centella asiatica, prefrontal cortex, Rattus norvegicus

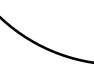

\section{PENDAHULUAN}

Berdasarkan data dari American Academy of Family Physicians, dua per tiga dari kunjungan ke dokter dikarenakan gejala yang berhubungan dengan adanya stres. Stres dapat berpengaruh terhadap kesehatan individu mulai dari mengganggu kinerja dalam hidup, memunculkan penyakit atau gangguan kejiwaan, bahkan dapat mengancam nyawa. ${ }^{1}$
Beberapa penyakit dilaporkan di negara barat yang berhubungan dengan stres, seperti gangguan memori dan konsentrasi, nyeri, kelelahan, iritabilitas, ansietas, serta perasaan hampa, dimana sering berkaitan dengan stres okupasional. Adapun individu yang mengalami stres dalam fase akut akan memiliki gejala hipertensi, nyeri dada, kepala terasa berputar, serta ketidakmampuan kognitif 
serius. Walaupun banyak individu yang dapat pulih dari gejala akut, akan terjadi peningkatan sensitivitas terhadap stres selama berbulan-bulan bahkan bertahuntahun, sehingga berefek pada individu untuk bekerja paruh waktu, mengganti pekerjaannya, ataupun pensiun dini. ${ }^{2}$

Adanya penurunan fungsional dari korteks prefrontalis yang terjadi selama stres berhubungan erat dengan kehilangan kemampuan dari kontrol diri dan berpotensi untuk perilaku maladaptif seperti merokok, meminum alkohol, dan makan yang berlebihan. $^{3}$

Respon sel tubuh terhadap stres tergantung pada tipe dan level stres yang mempengaruhinya, misalnya dapat berupa aktivasi untuk bertahan hidup hingga kematian sel terprogram. Kematian sel terprogram berupa apoptosis, autofagi, ataupun nekrosis yang berhubungan dengan perkembangan, penyakit degeneratif, dan kanker. ${ }^{4}$

Penelitian mengenai khasiat tanaman herbal untuk mengobati penyakit, tampaknya tidak dapat dihilangkan dengan pengobatan medis. Pengobatan herbal merupakan terapi tertua yang telah dilakukan sejak puluhan ribu lampau dalam sejarah pengobatan di dunia, seperti di daerah Cina, India, dan Mesir dimana tanaman herbal telah digunakan merawat gejala penyakit, menstimulasi daya tahan tubuh serta sebagai penyeimbang cairan tubuh. Bahkan $80 \%$ penduduk di dunia menggunakan tanaman herbal sebagai pilihan pengobatan dokter dengan ditunjang berbagai budaya dan kebiasaan setempat, contohnya berbagai rumah sakit di Cina mendidik dokter untuk menjadi spesialis pengobatan herbal serta mayoritas dokter di Jerman yang juga menggunakan terapi herbal. $^{5}$

Salah satu tumbuhan herbal yang digunakan di India dan Nepal yaitu Centella asiatica atau di Indonesia disebut pegagan. Bagian-bagian dari tumbuhan ini diyakini dapat memberikan dampak yang baik, berupa bagian akar dan daun untuk kesehatan pembuluh darah vena, memperbaiki kerusakan kulit, membantu perbaikan memori dan meningkatkan kerja otak. Kandungan kimia dari tumbuhan pegagan adalah trisakarida, dan derivat triterpenoid berupa madecassol yang bermanfaat dalam penyembuhan luka dan pembuluh darah. Berbagai penelitian lebih berpusat pada kandungan pegagan seperti asiaticosida, triterpenoid, centellosida, madecassonida, dan asam asiatik. Asiaticosida berdampak pada ansiolitik, antiinflamasi, antioksidan, antiulserasi. 
Dalam proses penyembuhan luka, Laboratorium Histologi Fakultas asiaticosida dan madecassonida efektif Kedokteran Universitas Islam Indonesia menyembuhkan artritis, sedangkan asam asiatik menginduksi apoptosis dan menghentikan siklus sel pada berbagai tipe kanker di tikus. ${ }^{6}$

Penelitian lain memaparkan efek protektif dari pegagan (Centella asiatica) terhadap penyakit yang menyerang sistem saraf pusat, dikarenakan derivat triperten seperti asam asiatik, asam madecasik, asiatikosida, madekasonida, dan asam brahmida. Efek neuroprotektif ini terlihat dari mekanisme yang berbeda-beda namun berdampak positif. ${ }^{7}$

Berdasarkan latar belakang tersebut penting dilakukan penelitian mengenai pengaruh pemberian ekstrak etanol pegagan (Centella asiatica) terhadap jumlah sel neuron di Korteks Prefrontalis tikus putih (Rattus norvegicus) yang diberi perlakuan stres.

\section{METODE PENELITIAN}

Penelitian yang digunakan adalah eksperimental dengan rancangan posttest with control group design. Penelitian dilakukan di Laboratorium Fisiologi Fakultas Kedokteran Universitas Gajah Mada, Laboratorium Histologi Fakultas Kedokteran Universitas Gajah Mada dan pada Januari-Februari 2015. Penelitian ini telah mendapat persetujuan dari Komite Etik Penelitian Kedokteran dan Kesehatan Fakultas Kedokteran Universitas Islam Indonesia 77/Ka.Kom.Et/70/KE/III/2015. Populasi penelitian ini adalah 12 ekor tikus Wistar dengan kriteria jenis kelamin jantan, sehat (tidak tampak ada gejala sakit dan tikus aktif), usia 2-3 bulan dan berat 250-300 gram. Tikus dibagi menjadi 2 kelompok secara acak dan masing-masing kelompok terdiri dari 6 ekor tikus. Kelompok I adalah kelompok kontrol (K) dan kelompok II adalah kelompok perlakuan $(\mathrm{P})$

\section{Pembuatan Ekstrak Daun Pegagan}

Pertama dilakukan pencucian daun, pengeringan dan penyerbukan daun pegagan. Selanjutnya, serbuk daun pegagan beserta petiolanya dimasukkan ke dalam maserator berpengaduk listrik seraya ditambah etanol $70 \%$ dan diaduk terus menerus selama 30 menit. Setelah itu, ekstrak dibiarkan termaserasi selama 24 jam, kemudian disaring dengan kertas saring dan penyaringan dilakukan sebanyak 2 kali, maka diperoleh filtrat. Filtrat selanjutnya diuapkan dengan evaporator 
berotasi (nilai kemampuan ekstrak 1012\%), hingga kental. Filtrat kental sebanyak $60 \mathrm{mg}$ dilarutkan dengan $1 \mathrm{ml}$ Pulvis Gum Arabia (PGA) 3\%

\section{Perlakuan pada Hewan Coba}

Tikus uji dilakukan adaptasi dalam kandang selama 7 hari tanpa adanya perlakuan stres. Pada kelompok kontrol (K) diberikan Pulvis Gum Arabia (PGA) 3\% sebanyak $1 \mathrm{ml}$ dengan menggunakan sonde pada saat 30 menit sebelum stres diberikan, sedangkan pada kelompok perlakuan (P) diberikan ekstrak etanol daun pegagan dengan dosis $300 \mathrm{mg} / \mathrm{kgBB} / \mathrm{hari}$ dengan menggunakan sonde pada 30 menit sebelum stres diberikan. Setelah itu, dimulai tahap perlakuan stres restrain dengan cara memasukkan tikus dalam tabung yang berukuran panjang $15 \mathrm{~cm}$ dan berdiameter 5,5 $\mathrm{cm}$ dengan beberapa lubang dengan ukuran $3 \mathrm{~mm}$ di kedua ujungnya 6 jam/hari (09.00-15.00) selama 21 hari.

\section{Pengambilan Jaringan Otak}

Sehari setelah perlakuan terakhir semua tikus pada masing masing dilakukan pembedahan dengan anestesi Xylazine $1 \mathrm{ml} / \mathrm{kgBB} \quad$ secara intramuskular, selanjutnya diambil bagian otaknya untuk diteliti.

\section{Pembuatan preparat}

Jaringan otak yang sudah difiksasi dengan formalin dibuat sediaan blok parafin lalu dipotong dengan mikrotom untuk dibuat sediaan preparat. Pengecatan dilakukan dengan pewarnaan toluidine blue.

\section{Pengamatan preparat}

Pengamatan preparat dilakukan dengan menggunakan mikroskop cahaya Olympus CX41 dengan perbesaran 400X yang terhubung dengan kamera Olympus E330. Pengambilan gambar dilakukan pada semua lapang pandang dari preparat.

\section{Analisis Data}

Rerata jumlah sel neuron di Korteks Prefrontalis dihitung dari total jumlah sel neuron seluruh lapang pandang dibagi jumlah lapang pandang. Sel neuron yang dihitung adalah sel yang masih memiliki inti yang terlihat jelas Perhitungan jumlah sel dilakukan dengan sofware Image J. Kemudian dilakukan uji Saphiro-Wilk. Perbedaan kedua kelompok diuji dengan independent T-test.

\section{HASIL PENELITIAN}

Pada penelitian ini, dari 12 tikus uji yang digunakan, tidak ditemukan tikus yang mati hingga penelitian berakhir. 


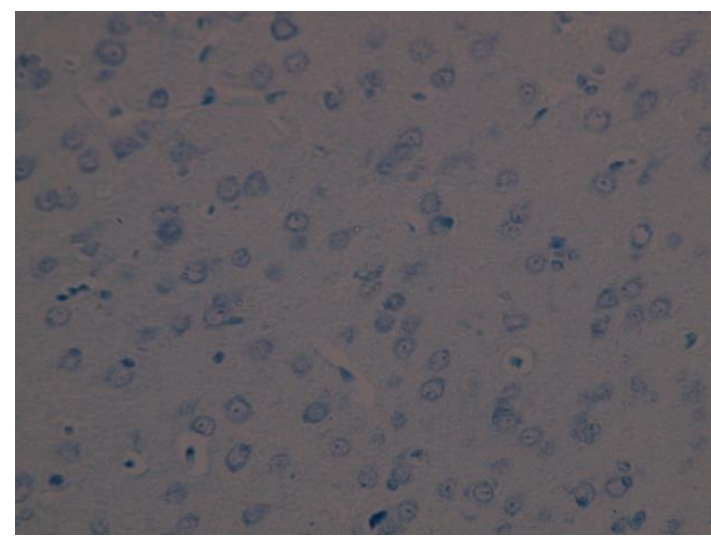

A

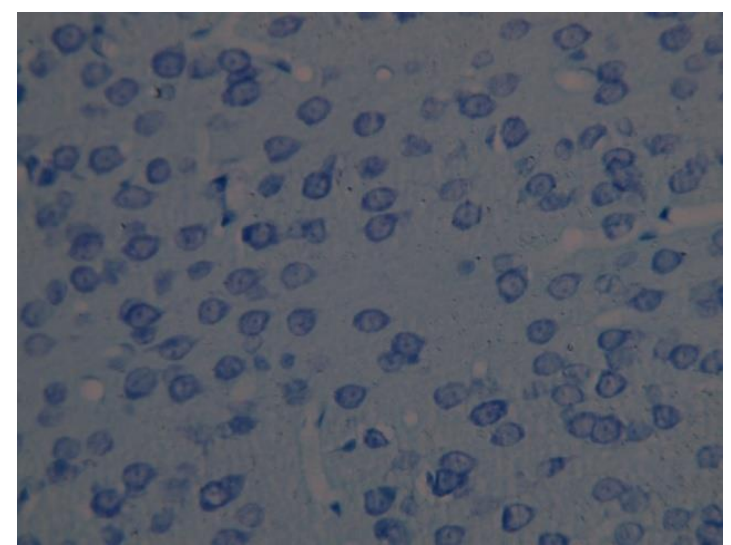

B

Gambar 1. Morfologi Sel Neuron. A merupakan kelompok tikus yang diberikan stres namun tanpa pemberian ekstrak pegagan (kelompok kontrol). Gambar B adalah tikus yang diberikan perlakuan stres dan ekstrak daun pegagan (kelompok perlakuan)

\section{Morfologi Sel Neuron}

Pada pengamatan preparat, Gambar

1A menunjukkan bahwa kelompok kontrol

(K) tingkat kerapatan sel tampak lebih rendah dibandingkan dengan Gambar 1B yaitu dari kelompok perlakuan. Hal ini jelas. serta beberapa vakuolisasi ekstraselular (terlihatnya adanya ruang jernih dengan berbagai ukuran yang terletak di luar sel). Gambar 1B menunjukkan sebaliknya, sel tampak rapat, inti dan sitoplasma terlihat

Tabel 1. Rerata Jumlah Sel Neuron Tikus

\begin{tabular}{cccc}
\hline Kelompok & $\mathbf{N}$ & $\begin{array}{c}\text { Rata-Rata Jumlah Sel } \\
\text { Neuron } \pm \text { SD }\end{array}$ & P \\
\hline $\mathbf{K}$ & 6 & $40,97 \pm 9,06$ & $0,004^{*}$ \\
$\mathbf{P}$ & 6 & $63,30 \pm 11,58$ & \\
\hline Keterangan: K & tikus yang diberi perlakuan stres restrain; P: tikus yang diberi & yang \\
perlakuan stres & restrain dan ekstrak etanol pegagan dengan dosis $300 \mathrm{mg} / \mathrm{kgBB} / \mathrm{hari} ;$ \\
$*$ signifikan &
\end{tabular}

menggambarkan bahwa sel neuron pada Gambar 1A telah mengalami kerusakan, tampak beberapa sel neuron tak berinti, sel neuron yang lebih kecil dan seperti berkerut, kromatolisis (neuron yang tampak bengkak dengan sitoplasma pucat serta inti sel yang bergerak ke arah batas margin),

\section{Jumlah Sel Neuron}

Jumlah rerata sel neuron kedua kelompok dapat dilihat di Tabel 1. Dalam Tabel tersebut tampak jumlah sel neuron kelompok kontrol relatif lebih rendah dibandingkan kelompok perlakuan. 
Berdasarkan uji T-Test Independen, mempunyai nilai p sebesar $0,004(\mathrm{p}<0,05)$, artinya terdapat perbedaan yang signifikan antara jumlah sel neuron kelompok kontrol dan kelompok yang diberi ekstrak daun pegagan yang diinduksi stres restrain.

\section{PEMBAHASAN}

Pada penelitian ini, kelompok kontrol (stres restrain) mengalami penurunan jumlah sel neuron pada setiap lapang pandang. Pemberian stres restrain jangka pendek dapat membantu proses penyesuaian diri, namun bila stres diberikan berulang-ulang menyebabkan kelebihan alostatik, maladaptasi terhadap respon sistem tubuh, dan terjadinya kerusakan permanen baik jaringan perifer maupun sistem saraf pusat, seperti terhambatnya neurogenesis hipokampus, adanya atrofi dendrit, bahkan neuron secara keseluruhan akan menghilang. ${ }^{8}$

Stres mestimulasi Aksis HipotalusPituitari-Adrenal (HPA) berlebihan. Hal ini akan memicu depresi dan merangsang sekresi glukokortikoid dari kelenjar adrenal. Pada otak postmortem pasien depresi terdapat adanya fragmentasi dan apoptosis neuronal. Adapun gangguan mood juga dapat menyebabkan kehilangan jumlah neuron dan menurunkan neurogenesis ${ }^{9}$.
Paparan stres secara kronik menurunkan jumlah neuron di Korteks Prefrontalis bagian medial. Hal ini karena neuron memiliki caspase-3 aktif. Ketika caspase-3 akif pada suatu sel neuron, maka sel tersebut akan cenderung untuk mati ${ }^{9}$.

Stres restrain kronik, menyebabkan penurunan panjang total dari apikal dendrit sel piramidal prefrontrokortikal pada area prelimbik, karena dapat menginduksi defisit kandungan dopamin dan/atau monoamin lain. $^{10}$

Pada kelompok perlakuan (stres restrain dan ekstrak etanol pegagan 300 mg) memiliki jumlah neuron rerata yang relatif lebih tinggi dibandingkan kelompok kontrol (stres restrain). Hasil penelitian ini menunjukkan bahwa ekstrak etanol pegagan (Centella asiantica) memiliki efek neuroprotektif dengan mencegah kematian sel neuron, sesuai dengan penelitian lain yang menjelaskan bahwa efek neurotropik langsung pada pemberian ekstrak aqueous pegagan (Centella asiatica), menyebabkan peningkatan yang signifikan pada arborisasi dendrit basal dan apikal pada neuron hipokampus pada tikus neonatal yang artinya pegagan memiliki efek biologis yang berhubungan dengan memori, pembelajaran, usia, dan berpotensi untuk 
menurunkan perkembangan penyakit Alzheime. ${ }^{11}$

Ekstrak pegagan juga memiliki efek protektif melawan neurotoksisitas dengan induksi aluminium pada korteks serebral, striatum, hipotalamus, dan hipokampus. Ekstrak pegagan (Centella asiatica) mampu meningkatkan level antioksidan endogenous berupa aktivitas enzim superoksida dismutase (SOD), katalase (CAT), glutation, dan glutation-Stransferase dari region otak mencapai jumlah yang normal dibandingkan kontrol walaupun perubahannya tidak signifikan. Pada pemeriksaan histologis dengan pewarnaan Nissl-stained dark neuron $(N D N)$ terlihat adanya neuron pseudopalisading seperti amoeboid yang merupakan tanda neurodegenerasi dan kerusakan ekstensif dengan jumlah sel neuron yang hilang dengan neuron atropik, sitoplasma shrunken, dan kerusakan nukleus yang terdapat pada kelompok kontrol. Sedangkan pada kelompok perlakuan yang diberikan ekstrak pegagan (Centella asiatica) terdapat penurunan kehilangan jumlah sel neuron yang signifikan. $^{12}$

Produk natural Centella asiatica memodulasi sel neuron untuk mampu bertahan hidup dengan mengubah jaras caspase-9. Penelitian ini mengevaluasi potensial neuroprotektif dari ekstrak etanol Centella asiatica berkadar rendah mampu memproteksi sel dari stress oksidatif dengan menggunakan sel neuroblastoma manusia SH-SY5Y. Sel SH-SY5Y ini menginduksi secara signifikan aktivitas caspase 8 dan caspase 9 dimana dapat mengaktivasi jalur apoptosis sel neuron, namun dengan ekstrak Centella asiatica $1 \mu \mathrm{g} / \mathrm{ml}$ menurunkan aktivitas capspase-9 secara signifikan sehingga apoptosis sel lebih rendah dibandingkan kelompok kontrol. $^{13}$

\section{Keterbatasan Penelitian}

Penelitian ini hanya menggambarkan jumlah sel neuron rerata dengan penghitungan kasar tanpa merincikan jenis sel-sel neuron yang berada di Korteks Prefrontalis, sehingga tidak dapat mengetahui pasti jenis sel neuron yang manakah yang mengalami penurunan jumlah rerata dengan pengaruh stres restrain ini.

\section{KESIMPULAN DAN SARAN}

\section{Kesimpulan}

Dari hasil penelitian ini dapat disimpulkan bahwa pemberian ekstrak etanol pegagan (Centella asiatica) berpengaruh terhadap peningkatan jumlah 
sel neuron di Korteks Prefrontalis tikus putih (Rattus norvegicus). Oleh karena itu Pegagan (Centella asiatica) dapat menghambat kematian sel akibat stres restrain (stres yang diakibatkan keterbatasan gerak).

\section{Saran}

Untuk mendapatkan hasil yang lebih baik maka diperlukan variasi dosis ekstrak etanol pegagan dalam memberikan pengaruh terhadap jumlah sel neuron serta meningkatkan keterampilan dalam mengambil gambar dengan menggunakan kamera yang terhubung dengan mikroskop sehingga menciptakan kualitas gambar yang lebih baik. Perlu dilakukan penelitian lebih lanjut untuk mengetahui perkiraan jenis -jenis sel neuron yang berpengaruh terhadap stres yang diberikan sehingga dapat merincikan jumlah sel dengan jenis apa yang mengalami penurunan jumlah terhadap stres restrain yang diberikan. Selain itu mengenai penelitian efek toksik ekstrak etanol pegagan dengan dosis yang lebih tinggi dan dalam jangka waktu lama.

\section{DAFTAR PUSTAKA}

1. Cotton DHG. Stress Management: An Integrated Approach to Therapy. Brunner/Mazel, New York. 2013
2. Blik E, Perski A, Berglund H, Savic I. Long-Term Occupational Stress is Associated with Reductions in Brain Tissue Volumes. PLoS ONE, 2013 8(6): 1-9.

3. Arnsten AF. Stress Signaling Pathways that Impair Prefrontal Cortex Structure and Function. National Review Neuroscience, 2009 10(6):410-422.

4. Fulda S, Gorman AM, Hori O, Samali A. Cellular Stress Responses: Cell Survival and Cell Death. International Journal of Cell Biology, 2010: 1-23.

5. Wijayanti D. Sehat dengan Pengobatan Alami. Venus, Yoyakarta.2009.

6. Tiwari S, Gehlot SS, Gambhir I. Centella asiatica: A Concise Drug Review with Probable Clinical Uses. Journal of Stress Physiology and Biochemistry 7(1):38-44.

7. Orhan IE. Centella asiatica (L.) Urban: From Traditional Medicine to Modern Medicine with Neuroprotective Potential. Evidence-Based Complementary and Alternative Medicine, Review Article, 2012 $:: 1-8$.

8. Zimprich AEL. Impact of Acute and Chronic Restraint Stress on Behaviour and Neuronal Morphology in Genetically Modified Mouse Models. Disertasi, Technischen Universität München. 2013.

9. Bachis A, Cruz MI, Nosheny RL, Mocchetti I. Chronic Unpredictable Stress Promotes Neuronal Apoptosis in the Cerebral Cortex. Neurosci Lett, 2008 442(2): 104-108.

10. Perez-Cruz C Hemispheric and RegionSpecific Effects of Chronic Stress in The Rat Prefrontal Cortex, Disertasi, GeorgAugust-Universität Göttingen. 2007

11. Reddy C, Rudra M, Raju E, Venkata NR, Reddy, M, Sadananda M, Manjunatha P. Role of Medicinal Plants in the Treatment of Alzheimer's Disease: A Review. Scholars Academic Journal of Pharmacy, 2013 2(1): 21-26.

12. Amjad S, Umesalma S. Protective Effect of Centella asiatica against AluminiumInduced Neurotoxicity in Cerebral Cortex, Striatum, Hypothalamus and Hippocampus of Rat BrainHistopathological, and 
Biochemical Approach. Journal Molecule Biomark Diagnosis, 2015 6(1):1-7.

13. Juźwiak S, Wójcicki J, Mokrzycki K, Marchlewicz M, Białecka M, WendaRóżewicka L, et al. Effect of quercetin on experimental hyperlipidemia and atherosclerosis in rabbits. Pharmacology Reports, 2005 57: 604-9.

14. Omar NS, Zakaria, Zatty AC, Mian TS, Ngah, WZW, et al. Centella asiatica Modulates Neuron Cell Survival by Altering Caspase-9 Pathway. Journal of Medical Plant Research, 2011 5(11): 22012109. 